\title{
DOI 10.26886/2520-7474.5(37)2019.4
}

\section{UDC 351.84:364}

\section{IMPLEMENTATION OF STATE SOCIAL POLICY IN UKRAINE}

\section{V. Plotka, graduate student}

Dnipro State Agrarian and Economic University, Dnipro

The article explores the state and prospects of social policy development in Ukraine. The purpose of the article is to determine the main directions of social policy implementation in Ukraine, the subject composition of social policy. Methods which was used in the article: analytical, statistical, monographic. The study revealed the patterns of socio-economic turmoil in Ukraine and their impact on the implementation of social policy. The haphazardness in the implementation of social policy in the country is emphasized. The main directions of reforming the system of social benefits and benefits are outlined, which must be subordinated to the following goals: constitutional, political, economic, social, financial.

Keywords: politics, social policy, mechanisms, benefits and payments.

аспірант, Плотка Л. В. Реалізація державної соціальної політики в Україні / Дніпровський державний аграрно-економічний університет, Дніпро

У статті досліджено стан та перспективи розвитку соціальної політики в Україні. Метою статmі є визначення основних напрямів реалізації соціальної політики в Україні, склад суб’єктів соціальної політики. Методи, які використовувались при написанні статті: аналітичний, статистичний, монографрічний. $B$ ході дослідження виявлено закономірності перебігу соціально-економічних перетоврень в Укріїні та їх вплив на реалізацію соціальної полтіики. Підкреслено безсистемність у реалізації соціальної політики в країні. Окреслено основні напрями рефрормуваня системи соціальних виплат 
та пілье, які мають бути підпорядковані наступним цілям: конституційним, політичним, економічним, соціальним, фрінансовим.

Ключові слова: політика, соціальна політика, механізми, пільги та виплати.

Постановка проблеми. Реалізацію соціальної політики неможливо розглядати без здійснення соціального захисту будь-якої категорії громадян. Відповідно соціальний захист $€$ важливою складовою соціальної політики та необхідним елементом функціонування держави в умовах ринкової економіки. В сучасних умовах гостро стоїть проблема ефективності соціального захисту населення. Значна частина населення перебуває за межею бідності. Держава внаслідок економічних можливостей не в змозі надати широкомасштабну допомогу всім категоріям населення, які опинилися в скрутному становищі. Сформована ситуація диктує необхідність поетапної реорганізації системи соціального захисту населення 3 метою пріоритетної підтримки найменш захищених верств на виборчій, адресній основі.

Окрім того прагнення України увійти до Європейської співдружнності країн та у Європейський Союз $є$ неможливим без створення системи правових, економічних, організаційних та інших заходів державних та недержавних установ та організацій, які впливатимуть та спрятимуть підтриманню соціальної стабільності, створенню умов для зростання добробуту населення, забезпеченню належного рівня та якості життя населення.

Аналіз останніх досліджень і публікацій. Дослідження проблем соціального захисту населення представлено у працях провідних науковців: Амоша О., Борецька Н.П., Давидюк С.О., Макарова О.В, Скуратівський В.А., Трощинський В.П., Чечель А.О. та інші. 
Мета статті. Метою статті $€$ визначення основних тенденцій і проблем реалізації державної соціальної політики в Україні.

Завданнями дослідження є:

- аналіз основних тенденцій соціальної політики в сучасному світі;

- окреслення основних суб'єктів соціальної політики.

- аналіз стану соціальної політики в Україні та визначення нарямів її удосконалення.

Виклад основного матеріалу. Згідно Конституції України основним завданням соціальної політики є така діяльність державних та громадських інститутів, суспільних груп та окремих осіб-суб'єктів соціальної політики, яка спрямована на реалізацію соціальних потреб людини, що забезпечують ії життєдіяльність та розвиток як соціальної істоти на основі відносин принципу соціальної справедливості при беззастережному дотриманні її громадянських прав та свобод.

Згідно Положення «Про Міністерство соціальної полтіики України» центральним органом виконавчої влади $є$ Міністерство соціальної політики України, діяльність якого спрямовується і координується Кабінетом Міністрів України і який забезпечує фрормування та реалізує державну політику у сфрері праці та соціальної політики, зайнятості населення та трудової міграції, трудових відносин, загальнообов'язкового державного соціального та пенсійного страхування, соціального діалогу, соціального захисту, волонтерської діяльності, з питань сім'ї та дітей, оздоровлення та відпочинку дітей, усиновлення та захисту прав дітей, запобігання насильству в сім'ї, протидії торгівлі людьми, захисту прав депортованих за національною ознакою осіб, які повернулися в Україну, а також забезпечує формування та реалізацію державної політики щодо пенсійного забезпечення та ведення обліку осіб, які підлягають 
загальнообов'язковому державному соціальному страхуванню, соціального захисту ветеранів війни та осіб, на яких поширюється дія Закону України "Про статус ветеранів війни, гарантії їх соціального захисту" в частині організації виплати їм разової грошової допомоги, соціальної та професійної адаптації військовослужбовців, які звільняються, осіб, звільнених 3 військової служби, у сфері промислової безпеки, охорони праці, гігієни праці, поводження 3 вибуховими матеріалами, здійснення державного гірничого нагляду, здійснення державного нагляду та контролю за додержанням вимог законодавства про працю, зайнятість населення, загальнообов'язкове державне соціальне страхування в частині призначення, нарахування та виплати допомоги, компенсацій, надання соціальних послуг та інших видів матеріального забезпечення з метою дотримання прав і гарантій застрахованих осіб

Основні сфери діяльності Міністерства соціальної політики наведено в таблиці 1 [7].

Таблиця 1

\section{Сфери діяльності Міністерства соціальної політики}

\begin{tabular}{|c|c|}
\hline Сфера діяльності & Напрями діяльності \\
\hline $\begin{array}{l}\text { Оплата й мотивація } \text { праці } \\
\text { працівників у виробничих галузях } \\
\text { та в бюджетній сорері }\end{array}$ & $\begin{array}{ll}\text { Вивчення перспективних } \\
\text { міжгалузевих проблем оплати } \\
\text { праці в різних виробничих галузях; } \\
\text { підготовка пропозицій про } \\
\text { мінімальний рівень оплати праці; } \\
\text { встановлення тарифних ставок та } \\
\text { посадових окладів для працівників } \\
\text { бюджетної сфери }\end{array}$ \\
\hline $\begin{array}{l}\text { Рівень життя і соціальний захист } \\
\text { населення }\end{array}$ & $\begin{array}{l}\text { Проведення моніторингу рівня } \\
\text { життя, доходів, умов і охорони } \\
\text { праці, аналіз структури й динаміки } \\
\text { доходів, розробка мінімальних } \\
\text { споживчих бюджетів та соціальних } \\
\text { пільг, компенсацій; вивчення } \\
\text { загальних питань пенсійного } \\
\text { забезпечення }\end{array}$ \\
\hline
\end{tabular}




\begin{tabular}{|c|c|}
\hline Організація праці & $\begin{array}{l}\text { Розробка форм і методів } \\
\text { організації та нормування праці, } \\
\text { тарифікація праці }\end{array}$ \\
\hline Підготовка і перепідготовка кадрів & $\begin{array}{l}\text { Розробка видів і методів } \\
\text { підготовки і перепідготовки кадрів } \\
\text { для ринкової } е \text { економіки, } \\
\text { прогнозування ринку професій та } \\
\text { профорієнтації } \\
\text { розробка міжрегіональних } \\
\text { міжгалузевих програм у цій сфрері }\end{array}$ \\
\hline Охорона та умови праці & $\begin{array}{l}\text { Розробка та узгодження норм } \\
\text { правил охорони та умов праці }\end{array}$ \\
\hline Соціальне страхування & 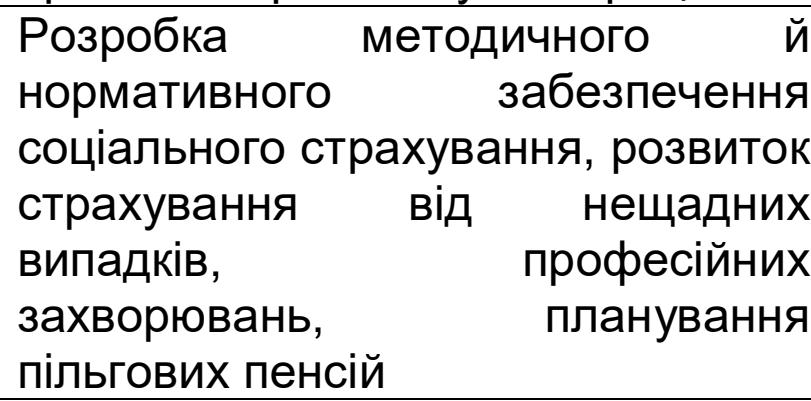 \\
\hline $\begin{array}{l}\text { Трудові відносини й соціальне } \\
\text { партнерство }\end{array}$ & 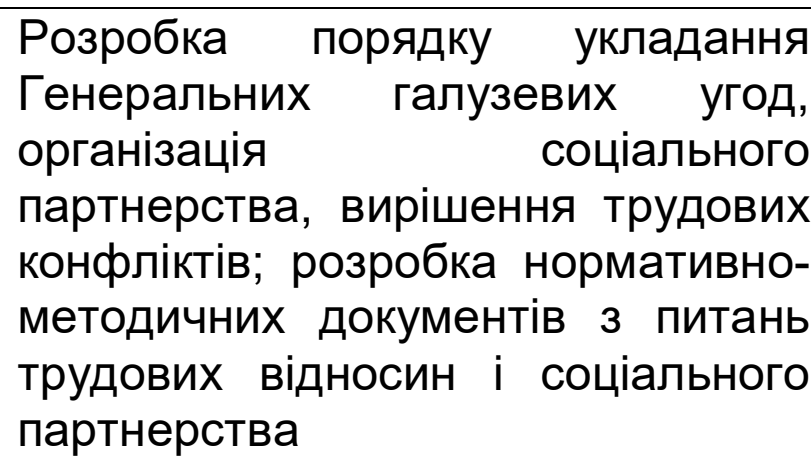 \\
\hline $\begin{array}{l}\text { Правове регулювання праці і } \\
\text { соціальних питань }\end{array}$ & $\begin{array}{l}\text { Підготовка та експертиза проектів } \\
\text { нормативних актів, систематизація } \\
\text { і аналіз трудового законодавства }\end{array}$ \\
\hline Міжнародне співробітництво & $\begin{array}{l}\text { Розробка пропозицій з питань } \\
\text { двостороннього співробітництва, } \\
\text { координація робіт з МОП, } \\
\text { вивчення } \\
\text { технічної допомоги }\end{array}$ \\
\hline
\end{tabular}

Починаючи з 2017 року Уряд України почав втілювати реформи, які стосуються реалізації соціальної політики. При цьому було поставлено завдання не пасивне пристосування соціальної політики до обмежених фрінансових та матеріальних ресурсів, а визначення основних пріоритетів та визначення основних напрямів покращення 
добробуту населення та втілення в життя принципів соціальної справедливості.

Основними пріоритетами було визначено:

- рефрорма системи оплати праці;

- пенсійна рефрорма;

- забезпечення адресності в наданні державної соціальної допомоги;

децентралізація системи соціальних послуг та їх розвиток на рівні територіальних громад.

Необхідність проведення реформ зумовлено підвищенням ефективності управління бюджетними коштами 3 метою підтримки соціально незахищених верств населення та визначеними цілями здійснюваних економічних реформ та реформ державного управління

в Україні [1]. В цьому контексті ключовими в соціальному розвитку регіонів стають: зайнятість, збереження та розвиток соціальної інфраструктури, забезпечення природного приросту населення, соціальна підтримка сім'ї, інвалідів, пенсіонерів, дітей, захист незахищених верств населення.

Окрім того пріоритетними завданнями у сфері соціального захисту та соціального забезпечення $€$ підвищення ефективності управління бюджетними коштами для державної підтримки соціально бідних верств населення, подальше реформування сфери надання соціальних послуг і соціального захисту [5].

Усього Міністерству соціальної політики України в держбюджеті на 2019 р. Урядом виділено 198,6 млрд грн. 3 них до Пенсійного фонду - 168 млрд грн. [11]. Станом на 1 півріччя 2019 року рівень виконання державного бюджету за виплатами становив 91 \%, зокрема видатки Міністерства соціальної політики становили 123, 8 млрд грн, що становить 97 \% від запланованої суми; пенсійного фонду 100\% [4]. 
Така ситуація пояснюється індексацією пенсій, підвищенням пенсійних виплат військовослужбовцям, виплатою разових пенсійних виплат для окремих категорій пенсіонерів. Всі ці підвищення були здійснено під час проведення виборів Президента України. В результаті утворилася додаткова потреба Пенсійного фонду у ресурсі в розмірі майже 30 млрд грн.

Разом з тим в цей період значно скорочено обсяг коштів на виплату пільг і житлових субсидій громадянам на оплату житловокомунальних послуг. Так, у 2018 році фрінансування цих видатків здійснювалось через Міністерство фрінансів в розмірі майже 71 млрд грн. У 2019 році зазначені видатки передано Мінсоцполітики (загальним обсягом 55,1 млрд грн) та розподілено між двома бюджетними програмами: «Виплата пільг і житлових субсидій громадянам на оплату житлово-комунальних послуг у готівковій формі» у сумі 20,0 млрд. грн.; «Субвенція 3 державного бюджету місцевим бюджетам на надання пільг та житлових субсидій населенню на оплату електроенергії, природного газу, послуг тепло-, водопостачання і водовідведення, квартирної плати (утримання будинків і споруд та прибудинкових територій), управління багатоквартирним будинком, поводження з побутовими відходами (вивезення побутових відходів) та вивезення рідких нечистот, внесків за встановлення, обслуговування та заміну вузлів комерційного обліку води та теплової енергії, абонентського обслуговування для споживачів комунальних послуг, що надаються у багатоквартирних будинках за індивідуальними договорами» у сумі 35,1 млрд. грн [4].

Порівняно з 2018 роком мінімальна зарплата у 2019 році зросла на 450 грн, тобто 12,08\% і становить 4173 грн.

Законом «Про державний бюджет України на 2019 рік» встановлено у 2019 році прожитковий мінімум на одну особу в 
розрахунку на місяць у розмірі з 1 січня 2019 року - 1853 гривні, 31 липня - 1936 гривень, з 1 грудня - 2027 гривень, а для основних соціальних і демографічних груп населення:

дітей віком до 6 років: 31 січня 2019 року - 1626 гривень, $з 1$ липня - 1699 гривень, з 1 грудня - 1779 гривень;

дітей віком від 6 до 18 років: з 1 січня 2019 року - 2027 гривень, 3 1 липня - 2118 гривень, з 1 грудня - 2218 гривень;

працездатних осіб: з 1 січня 2019 року - 1921 гривня, з 1 липня 2007 гривень, з 1 грудня - 2102 гривні;

осіб, які втратили працездатність: 31 січня 2019 року - 1497 гривень, з 1 липня - 1564 гривні, з 1 грудня - 1638 гривень.

Цим документом також встановлено, що у 2019 році рівень забезпечення прожиткового мінімуму для призначення допомоги відповідно до Закону України «Про державну соціальну допомогу малозабезпеченим сім'ям« у відсотковому співвідношенні до прожиткового мінімуму для основних соціальних і демографрічних груп населення становить: для працездатних осіб - 21 відсоток, для дітей 85 відсотків, для осіб, які втратили працездатність, та осіб 3 інвалідністю - 100 відсотків відповідного прожиткового мінімуму [4].

Розмір державної соціальної допомоги малозабезпеченим сім'ям у 2019 році не може становити більше 75 відсотків рівня забезпечення прожиткового мінімуму для сім'ї.

Тобто слід констатувати, що держава гпиагається підвищити рівень життя населення. Але, нажаль, діючі механізми підтримки незахищених верств населення не завжди ефективно реалізуються, застарілі або взагалі відсутні.

Серед проблем реформування соціального захисту населення велике значення надається реформуванню системі надання громадянам соціальних пільг і виплат. В умовах проведення ринкових 
реформ функціонування системи соціальних виплат і пільг, яка побудована на уравнітельних принципах $є$ неефективною [6]. Потреба в соціальній підтримці обумовлена низкою фракторів, в тому числі наявністю високого рівня бідності населення.

Слід констатувати, що діюча система соціальних виплат і пільг лягає важким тягарем на бюджети всіх рівнів та на економічні суб'єкти. Механізм реалізації багатьох пільг не розроблений, не забезпечується цілеспрямоване поєднання різних форм соціальної підтримки населення. Відсутні чіткі цілі встановлення пільг і принципи відбору груп населення, на які поширюються ці пільги. Сучасний механізм надання пільг призводить до розширення перехресних взаємозаліків бюджетів різних рівнів і численних комерційних структур (транспорт, зв'язок тощо).

Окрім того слід зазначити, що реалізація соціальної політики відбувається в умовах гострого дефіциту фінансових і матеріальних ресурсів. Механізм надання пільг хоча і має законодавче офрормлення i передбачає певний правопорядок і джерела їх ресурсного забезпечення, але на практиці часто не реалізується або не забезпечується у повному обсязі.

Рефрормування системи соціальних виплат і пільг, враховуючи масштабність вирішуваних завдань, повинно бути підпорядковане наступним цілям:

- конституційним: дотримання прав людини і громадян у сфрері соціального захисту, підвищення відповідальності підприємств, установ і організацій незалежно від форми власності, а також посадових осіб за забезпечення прав громадян у сфері надання населенню соціальних пільг.

- політичним: забезпечення соціальної стабільності в суспільстві і зниження соціальної напруженості; 
- соціальним: адресна підтримка малозабезпечених, які мають середній дохід на одну особу нижче прожиткового мінімуму; орієнтація заходів соціального захисту на індивідуальні потреби населення;

- фрінансовим: забезпечення раціонального використання коштів шляхом їх перерозподілу на користь найбільш нужденних, адаптація системи соціальних виплат і пільг до ринкових відносин, приведення соціальних зобов'язань держави у відповідність до фрінансовоекономічних можливостей їх надання;

- економічним: забезпечення конкурентного середовища предоставлення соціально важливих послуг і товарів.

Висновки і пропозиції. Отже, реалізація стратегічного курсу на досягнення в Україні європейських стандартів життя має ґрунтуватися насамперед на радикальному підвищенні якості та ефективності надання послуг соціальної сорери, створення та впровадження правових й організаційних умов недопущення зниження рівня життя населення України. Реформування системи соціальних виплат і пільг, враховуючи масштабність вирішуваних завдань, повинно бути підпорядковане наступним цілям: конституційним; політичним; соціальним; фрінансовим; економічним.

\section{תimepamypa:}

1. Амоша О., Новікова, О. (2005) Проблеми та шляхи забезпечення соціальної орієнтації економіки України. Журнал європейської економіки. 2. 179-180.

2. Борецька, Н.П. (2001) Соціальний захист населення на сучасному етапі: стан і проблеми. Монографрія. Донецьк: Янтар.

3. Давидюк, О.О. Соціальна політика в умовах поглиблення соціальної нерівності в Україні; Центр перспект. соц. дослід. - Режим доступу: http://www.cpsr.org.ua/index.php?option (2019, September, 21). 
4. Закон про Державний бюджет України на 2019 рік 2018 (Верховна Рада України). Відомості Верховної Ради Україниб 3. 31 Режим доступу: http://zakon2.rada.gov.ua/laws/show/1801-19 (2019, September, 21).

5. Макарова О. В. (2015) Соціальна політика в Україні. Київ: Ін-т демографії та соціальних досліджень ім. М.В. Птухи НАН України.

6. Прокопенко І.Ф., Олійник Ю.О. (2018) Державна соціальна політика як чинник економічного розвитку України. Збірник наукових праць Харківського національного педагогічного університету імені Г. С. Сковороди. 18. 4-13.

7. Скуратівський В.А., Трощинський В.П., Ситник П.К. (2012) Реформування соціальної політики в Україні: проблеми та перспективи. Львів, НАДУ.

8. Чечель А.О., Тарасенко Д.Л., Сухова К.К. (2017) Реалії та перспективи розвитку соціальної сфрери в умовах децентралізації. Проблеми та перспективи розвитку державного управління в умовах рефрормування: Польща, Вища школа економіки та гуманітаристики.

\section{References:}

1. Amosha O., Novikova O. (2005) Problemi ta shlahi zabezpechennja socialnkj orientaciji ekonomiki Ukraini [Problems of that hat for the protection of the social and economic economy of Ukraine], Zhurnal evropejskoi ekonomiki. [Journal of European Economics.], no2, 179-180 [in Ukranian].

2. Borecka N.P. (2001). Socialniy zahist naselennja na suchasnomu etapi: stan I problemi [Social protection of the population at the present stage: the state and problems.] Donetsk . Jantar [in Ukranian].

3. Davidjuk O.O. Socialnaja politika $v$ umovah pogliblennja socialnoi nerivnosti v Ukraini. Retrived from: http://www.cpsr.org.ua/index.php?option (2019, September, 21). 
4. Zakon pro dergavnij budget Ukraini 2019 (2018) (Verkhovna Rada Ukrainy). [Law of Ukraine "On the State Budget of Ukraine for 2019"]. Vidomosti Verhovnoi Rady Ukraini [Statemets of Verkhovna Rada of Ukraine,], no 50, 400 [in Ukranian]

5. Makarova O.V. (2015). Socialna politika v Ukraini [Social Policy in Ukraine]/ Kiyv. [in Ukranian].

6. Prokopenko I.Ph., Olijnik, Ju.O. (2018) Derjavna socialna politika jak chinnik economichnogo rozvitku Ukraini [State social policy as a factor of economic development of Ukraine.], Zbirnyk naukovykh prats' Kharkivs'koho natsional'noho pedahohichnoho universytetu imeni H.S. Skovorodi [Collection of scientific works of Kharkiv National Pedagogical University of G.S. Skovorodi], no 18, 4-13 [in Ukranian]

7. Skuratovsky V.A., Troshchinsky V.P., Sytnyk, P.K. (2012) Reformuvannya sotsial'noyi polityky $v$ Ukrayini: problemy ta perspektyvy [Reforming social policy in Ukraine: problems and prospects]. Lviv, NADU [in Ukranian]

8. Chechel A.O., Tarasenko D.L., Sukhova, K.K. (2017) Realiyi ta perspektyvy rozvytku sotsial'noyi sfery $v$ umovakh detsentralizatsiyi. Problemy ta perspektyvy rozvytku derzhavnoho upravlinnya $v$ umovakh reformuvannya [Realities and prospects of social sphere development in the conditions of decentralization. Problems and prospects of development of public administration in the conditions of reform]. Poland. Higher School of Economics and Humanities [in Ukranian] 